\title{
PENENTUAN HASIL EVALUASI PEMILIHAN SPESIES POHON DALAM PENGENDALIAN POLUSI UDARA PABRIK SEMEN BERDASARKAN KARAKTERISTIK MORFOLOGI
}

\author{
Fiona Azzahro*, Yulfiah, dan Anjarwati \\ Magister Teknik Lingkungan, Institut Teknologi Adhi Tama Surabaya \\ *e-mail: fiona.azzahro94@gmail.com
}

\begin{abstract}
The rapid development of the country in Indonesia, especially in the fields of industry and technology, is inseparable from the problem of air pollution, especially in the environment, namely pollutant gas and dust. Air pollution needs to be environmentally friendly by increasing the amount of vegetation or reforestation by planting tree species that have the ability to grow and absorb pollutant gases and absorb dust particles in polluted environmental conditions. The study uses descriptive analysis by assessing tree elements macroscopically to select the appropriate tree species and can be recommended as an absorber of gas pollutants and dust absorbers based on tree suitability scoring. The results showed that of 7 (seven) dominant tree species identified, there were 3 (three) dominant tree species that were very suitable, 3 (three) dominant tree species were suitable, and only 1 (one) dominant tree species were not suitable for air pollutant gas. Whereas the evaluation of the function of dust particle absorption shows that all dominant tree species studied have the appropriate criteria in absorbing dust with the acquisition of $65 \%-75 \%$ evaluation value.
\end{abstract}

Keywords: Dust, Pollutant, Pollution, Tree.

\begin{abstract}
Abstrak
Pesatnya dalam pengembangan pembangunan di negara Indonesia, khususnya bidang industri dan teknologi, tidak terlepas dari masalah pencemaran udara terutama pada lingkungan yaitu gas polutan dan debu. Pencemaran udara perlu dilakukan pengendalian ramah lingkungan dengan peningkatan jumlah vegetasi atau penghijauan dengan menanam spesies tanaman yang memiliki kemampuan tumbuh sertadapat menyerap gas polutan maupun menjerap partikel debu dalam kondisi lingkungan yang tercemar. Penelitian menggunakan analisis deskriptif dengan menilai elemen pohon secara makroskopis untuk memilih jenis pohon yang sesuai dan dapat direkomendasikan sebagai penyerap polutan gas dan penjerap debu berdasarkan skoring kesesuaian pohon. Hasil penelitian menunjukkan bahwa dari 7 (tujuh) spesies pohon dominan yang diidentifikasi, terdapat 3 (tiga) spesies pohon dominan yang sangat sesuai, 3 (tiga) spesies pohon dominan yang sesuai, dan hanya 1 (satu) spesies pohon dominan yang kurang sesuai untuk gas polutan udara. Sedangkan untuk evaluasi mengenai fungsi penjerapan partikel debu menunjukkan bahwa seluruh spesies pohon dominan yang diteliti memiliki kriteria sesuai dalam menjerap debu dengan perolehan nilai evaluasi $65 \%-75 \%$.
\end{abstract}

Kata kunci: Gas Asap, Bagasse, Abu, Rotary Dryer. 


\section{PENDAHULUAN}

Saat ini, pencemaran udara semakin menampakkan kondisi yang perlu mendapat perhatian. Kondisi ini diakibatkan dari segala sumber pencemaran udara dari berbagai kegiatan. Salah satunya berasal dari hasil kegiatan industri pabrik. Kegiatan dari industri pabrik termasuk memberikan kontribusi yang cukup besar dari pencemar udara yang dibuang bebas (Suhariyono dalam Hasibuan et al., 2015). Pencemar udara dari hasil emisi yang ditimbulkan oleh industri semen ini didominasi oleh debu yang mengandung silika yang teremisikan ke udara (Hesaki dalam Hasibuan, et al., 2015).

Pada umumnya debu atau partikel berasal dari material yang kasar melayang di udara dan bersifat toksik yang membahayakan bagi kesehatan manusia. Selain itu bahan-bahan pencemar tersebut juga akan menimbulkan dampak negatif lainnya seperti penurunan kualitas udara di sekitarnya dan juga dapat membahayakan kehidupan makhluk hidup lainnya seperti hewan dan tumbuhan (Fransiska, 2016). Oleh karena pentingnya kualitas udara, maka perlu adanya pengelolaan kualitas udara yang salah satunya adalah dengan pemantauan kualitas udara.

Sistem pemantauan kualitas udara berdasarkan informasi yang diperoleh dari Badan Perencanaan Pembangunan Nasional (BAPPENAS, 2006 dalam Haerani, 2011) dengan menggunakan jaringan pemantau otomatis yang dapat memantau konsentrasi CO, debu (PM 10), $\mathrm{SO}_{2}, \mathrm{NO}_{\mathrm{x}}$, dan Ozon $\left(\mathrm{O}_{3}\right)$. Namun sistem pemantauan kualitas udara ambien seperti itu memerlukan biaya investasi, operasional, dan perawatan yang cukup tinggi.

Terbatasnya alat pemantau dan dana serta terfokusnya pengamatan pada jalan raya sehingga pengambilan sampel tidak mewakili secara keseluruhan. Oleh karena itu, diperlukan suatu pertimbangan atau cara alternatif tentang penggunaan cara lain yang pembiayaannya lebih murah, sederhana, akurat yaitu dengan melakukan peningkatan tanaman/vegetasi.

Peningkatan jumlah vegetasi atau cara penghijauan dengan menanam pohon-pohon merupakan solusi dalam mengatasi masalah pencemaran udara di industri pabrik, sehingga konsentrasi partikel debu di sekitar pabrik menurun. Peningkatan jumlah vegetasi juga berfungsi sebagai penyaring dan penetral bahan-bahan pencemar udara sehingga dapat dijadikan suatu bioindikator untuk pemantauan kualitas udara, serta sebagai penghasil oksigen $\left(\mathrm{O}_{2}\right)$ yang sangat dibutuhkan oleh makhluk hidup.

Penanggulangan pencemaran udara oleh vegetasi/tumbuhan dapat dilakukan melalui 2 (dua) proses yaitu proses penyerapan (absorpsi) dan penjerapan (adsorpsi) (Al-Hakim, 2014). Tanaman akan menyerap dan menjerap polutan yang dihasilkan melalui daun. Tanaman berperan efektif dalam menyerap (absorbsi) polutan udara dan mampu membersihkan polutan tersebut dari udara.

Penelitian ini bertujuan untuk merekomendasikan spesies pohon yang berpotensi untuk menurunkan pencemaran gas polutan dan debu di sekitar kawasan pabrik semen. 


\section{METODE PENELITIAN}

Penelitian dilaksanakan pada bulan Januari-Februari 2018 di kawasan pabrik semen yang berlokasi di Kabupaten Bogor. Perlengkapan yang digunakan antara lain alat tulis dan kamera untuk dokumentasi, kalkulator, serta komputer. Sedangkan bahan yang digunakan dalam penelitian ini antara lain data fisik pohon yang bersumber dari studi pustaka literatur. Prosedur penelitian dilakukan dengan melalui beberapa tahapan yaitu:

1) Inventarisasi

Pada tahap inventarisasi dilakukan pengumpulan data-data yang digunakan untuk penelitian berupa data-data hasil observasi/pengamatan langsung di lapang maupun bersumber dari literatur. Jenis data vegetasi menggunakan parameter berupa data spesies pohon yang termasuk ke dalam bentuk data primer yang bersumber dari survey lapangan. Sedangkan jenis data standar fungsi ekologis jalur hijau menggunakan parameter berupa karakteristik tanaman untuk menyerap polutan sebagai data sekunder yang bersumber dari literatur atau pustaka (Al-Hakim, 2014).

2) Identifikasi Jenis Vegetasi

Tahap identifikasi jenis vegetasi yang ditanam dilakukan secara deskriptif dengan pengamatan langsung secara visual untuk mengetahui jenis-jenis pohon yang ditanam di kawasan pabrik semen. Jenis pohon pada tapak yang terpapar polusi dibatasi atau dipilih yang dominan pada kawasan industri pabrik semen. Hasil akhir dari identifikasi jenis vegetasi dapat disajikan berupa tabel jenis-jenis pohon (Aji, 2018).

3) Analisis

Pada tahap ini dilakukan analisis terhadap data-data yang didapatkan pada hasil inventarisasi. Analisis dilakukan secara deskriptif terhadap fungsi ekologis kawasan hijau yaitu fungsi ekologis untuk mengurangi polusi udara, yang kemudian dibagi menjadi fungsi menyerap gas polutan dan menjerap debu (Al-Hakim, 2014). Fungsi menyerap polutan gas dan menjerap debu dibedakan berdasarkan mekanisme tanaman dalam mengurangi zat pencemar tersebut.

Penelitian dilakukan dengan analisis deskriptif untuk mengetahui kesesuaian karakter fisik masing-masing pohon yang ada di kawasan pabrik semen dalam mengurangi gas polutan dan debu dengan penilaian atau skoring pada masingmasing elemen pohon yang telah diindentifikasi pada kawasan pabrik semen. Penilaian tersebut dilakukan pada fungsi ekologis kawasan hijau untuk mereduksi polusi dan menjerap partikel yang nantinya akan didapat hasil yang sesuai untuk dijadikan rekomendasi.

Penilaian dilakukan terhadap elemen pohon pada kawasan hijau, dengan membandingkan ciri fisik serta kondisi lapang vegetasi pada kawasan hijau dengan kriteria-kriteria yang dikumpulkan dari berbagai sumber pustaka terhadap fungsi kawasan hijau dalam menyerap gas polutan dan menjerap debu. Adapun kriteria fungsi ekologis tanaman tersebut ditunjukkan pada Tabel 1.

Tabel 1. Kriteria Penilaian Ekologis Pohon

\begin{tabular}{cl}
\hline Aspek Fungsi Pohon & \multicolumn{1}{c}{ Kriteria Penilaian } \\
\hline Penyerap gas polutan & 1. Kepadatan tajuk \\
& 2. Terdiri atas beberapa lapis tanaman dan terdiri dari \\
\hline
\end{tabular}


kombinasi semak, perdu, dan ground over

3. Daun tipis

4. Jumlah daun banyak

5. Jarak tanam rapat

Penyerap debu

1. Struktur permukaan, tepi daun kasar, berlekuk, berbulu/bertrikoma

2. Daun jarum atau daun lebar

3. Kepadatan tajuk

4. Tekstur kulit batang dan ranting kasar, ranting berduri

5. Kepadatan ranting

Sumber: Al-Hakim (2014)

Penilaian dilakukan untuk tiap jenis pohon. Untuk masing-masing kriteria penilaian diberikan dengan nilai antara 1 hingga 4 berdasarkan kesesuaian ciri fisik dan kondisi lapang pohon dengan kriteria penilaian dimana nilai 1 berarti tidak sesuai, 2 berarti kurang sesuai, 3 berarti sesuai, dan 4 berarti sangat sesuai dengan kriteria penilaian. Nilai maksimal atau nilai ideal untuk tiap kriteria adalah 4 .
Nilai yang didapat dari tiap kriteria dijumlahkan kemudian dibandingkan dengan jumlah ideal atau nilai maksimum dari tiap kriteria penilaian. Hasil perbandingan kemudian diubah ke dalam bentuk persen untuk mendapatkan persentase nilai evaluasi. Dari penilaian tersebut didapatkan hasil penilaian dalam bentuk persentase (Hidayat, 2008).

$$
\text { Nilai Evaluasi }=\frac{\text { jumlah total kriteria penilaian }}{\text { jumlah total nilai ideal kriteria penilaian }} \times 100 \%
$$

Hasil penilaian tersebut dikelompokkan dalam 4 kategori penilaian yaitu sangat sesuai, sesuai, kurang sesuai, dan tidak sesuai. Pengelompokkan hasil penilaian menggunakan 5 selang dengan nilai bobot sempurna yaitu $100 \%$ dibagi menjadi 5 selang sama besar, sebesar $20 \%$. Nilai $100 \%-81 \%$ merupakan kategori sangat sesuai, $81 \%-61 \%$ merupakan kategori sesuai, 60\%-41\% merupakan kategori kurang sesuai, dan nilai $40 \%$ atau kurang dari itu termasuk kategori tidak sesuai.

Untuk penelitian ini, selang $40 \%$ terendah dikelompokkan dalam satu kategori tidak sesuai. Pembobotan $40 \%$ terendah untuk kategori tidak sesuai ditujukan untuk meningkatkan standar penilaian (Hidayat, 2008). Pengelompokan persentase pembobotan aspek fungsi kawasan hijau adalah sebagai berikut:

Tabel 2. Pengelompokan Persentase Pembobotan Fungsi Ekologis Pohon

\begin{tabular}{cll}
\hline Skor & Kesesuaian & $\begin{array}{c}\text { Persentase Hasil } \\
\text { Penilaian }\end{array}$ \\
\hline 4 & $\begin{array}{l}\text { Sangat } \\
\text { sesuai }\end{array}$ & $>$ terpenuhi \\
\hline
\end{tabular}




\begin{tabular}{rll}
\hline Skor & Kesesuaian & $\begin{array}{c}\text { Persentase Hasil } \\
\text { Penilaian }\end{array}$ \\
\hline 3 & Sesuai & $\begin{array}{l}61-80 \% \text { kriteria } \\
\text { terpenuhi }\end{array}$ \\
\hline 2 & $\begin{array}{l}\text { Kurang } \\
\text { sesuai }\end{array}$ & $\begin{array}{l}41-60 \% \text { kriteria } \\
\text { terpenuhi }\end{array}$ \\
\hline 1 & Buruk & $\begin{array}{l}\leq 40 \% \text { kriteria } \\
\text { terpenuhi }\end{array}$ \\
\hline
\end{tabular}

Sumber: Hidayat (2008).

Setelah dilakukan penilaian terhadap pohon kawasan hijau, didapatkan nilai kuantitatif dan kualitatif dari vegetasi jalan untuk fungsi penyerapan gas polutan dan debu.

4) Rekomendasi

Tahap rekomendasi merupakan tahap akhir dari penelitian ini. Rekomendasi yang diberikan didasarkan pada hasil dari penilaian dan skoring kesesuaian pohon dalam mengurangi gas polutan dan debu pada kawasan pabrik semen. Rekomendasi diberikan dalam bentuk deskriptif. Pemberian rekomendasi diharapkan dapat menjadi bahan masukan bagi perusahaan semen dalam mengembangkan perencanaan ruang terbuka hijau di area industri agar fungsi penyerapan terhadap gas polutan dan penjerapan debu dapat lebih optimal.

\section{HASIL DAN DISKUSI}

\subsection{Identifikasi Jenis Vegetasi Pohon di Kawasan Industri}

Jenis vegetasi pada kawasan salah satu pabrik semen di Kabupaten Bogor cukup beragam. Vegetasi yang ditanam sepanjang Jalur Hijau kawasan pabrik semen umumnya merupakan vegetasi yang berfungsi sebagai tanaman pengarah, peneduh, dan mereduksi polusi udara. Data identifikasi jenis vegetasi diperoleh dari pengamatan dan laporan tahunan pabrik semen. Jenis pohon yang diinventaris sebanyak 19 spesies pohon pada tapak yang terpapar polusi dan dibatasi atau dipilih yang dominan terdapat 7 spesies pohon yang ditemukan pada kawasan industri pabrik semen antara lain akasia berjumlah 171, dadap merah berjumlah 85, tanjung sebanyak 98, kersen terdapat 94, angsana ditemukan 91, kihujan sebanyak 119, dan ketapang berjumlah 87 .

\subsection{Analisis Fungsi Spesies Pohon Dominan di Kawasan Industri Semen dalam Menyerap Gas Polutan}

Analisis terhadap kemampuan suatu kawasan hijau dalam menyerap polusi dilakukan dengan melakukan penilaian terhadap pohon dominan yang ditanam di kawasan tersebut. Apabila vegetasi dapat memenuhi kriteria vegetasi yang memiliki fungsi ekologis dalam menyerap polusi, maka dapat dikatakan kawasan hijau dapat menyerap polusi dengan baik.

Pohon yang dapat menyerap polusi dengan baik memiliki beberapa kriteria diantaranya harus mempunyai tingkat kepadatan tajuk yang padat, terdiri dari kombinasi semak, perdu, dan tanaman penutup tanah dan memiliki jumlah daun yang banyak. Menurut Nasrullah (2001), untuk mengurangi jumlah polutan yang telah terlepas pada lingkungan dapat dikurangi dengan adanya vegetasi. Salah satu mekanisme tanaman dalam mereduksi polusi udara yaitu dengan proses difusi yaitu pemencaran polutan ke atmosfir yang lebih luas dengan menggunakan tajuk pohon. Ketika tajuk pohon memiliki ketinggian yang cukup, maka tajuk pohon dapat membelokkan hembusan angin ke atsmosfer yang lebih 
luas, sehingga konsentrasi polutan dapat menurun. Selain itu, daun yang mempunyai jumlah banyak serta kombinasi antara semak, perdu, dan tanaman penutup tanah dapat mengoptimalkan proses absorbsi yaitu suatu proses yang dilakukan oleh tanaman dalam melakukan penyerapan polutan gas melalui stotama dan masuk melalui jaringan daun.

Sifat daun yang tipis dimiliki pohon juga punya kemampuan dalam menyerap polusi yang baik. Daun pada suatu tanaman yang memiliki ketebalan yang tipis lebih mudah menyerap polutan dibandingkan daun yang tebal (Gambar 3B). Pohon yang mempunyai daun yang tebal, pada umumnya mempunyai jaringan yang tebal sehingga sulit untuk ditembus oleh polutan. Selain itu, struktur vegetasi serta semakin padat jarak tanam antar pohon pada suatu RTH maka kemampuan RTH tersebut dapat melakukan proses absorbsi, adsorbsi, difusi, dan deposisi terhadap polusi akan mejadi semakin baik.

Penggunaan variabel untuk menilai kesesuaian pohon berdasarkan fungsi ekologis dalam menyerap polusi diantaranya adalah kepadatan tajuk pohon, kombinasi pohon dengan tanaman semak, perdu, dan tanaman penutup tanah, ketebalan daun, jumlah daun, serta jarak tanam terhadap pohon lain.

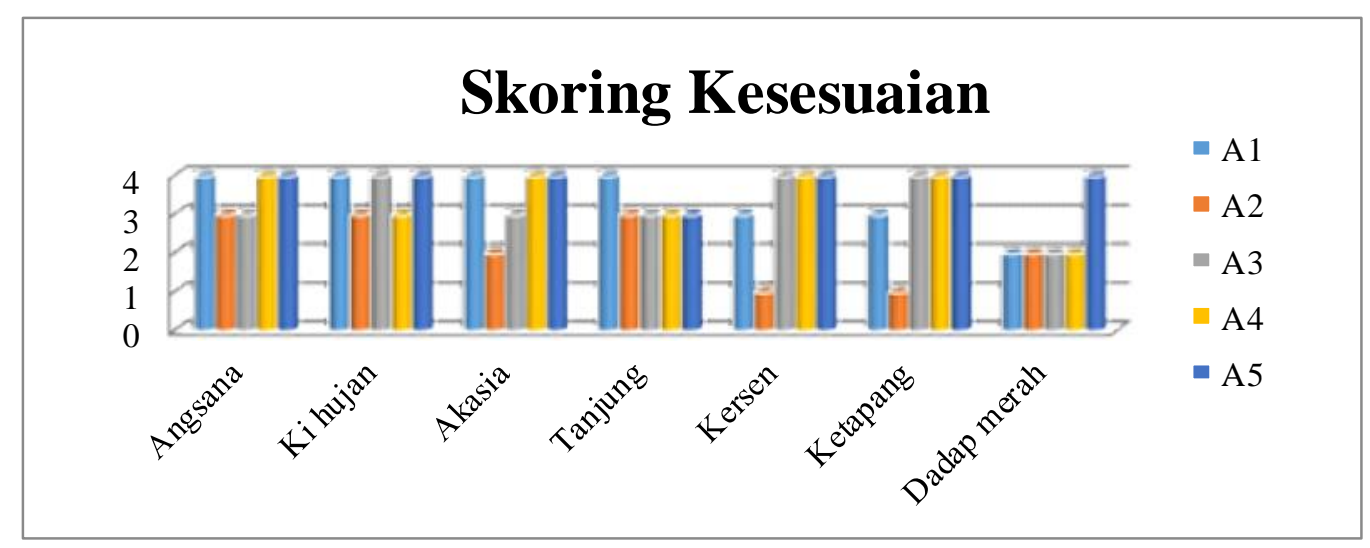

Gambar 1. Skoring Kemampuan Tanaman dalam Menyerap Gas Polutan

Keterangan:

A1 : Kepadatan tajuk

A2 : Terdiri atas beberapa lapis tanaman (semak, perdu, ground cover)

A3 : Daun tipis

A4 : Jumlah daun banyak

A5 : Jarak tanam rapat 


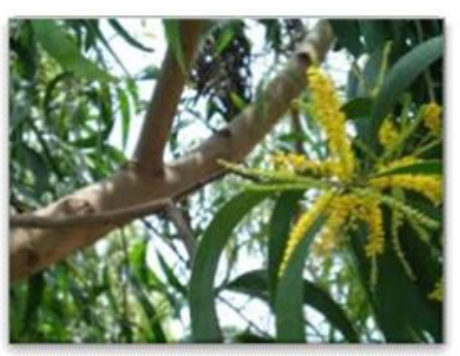

(A)

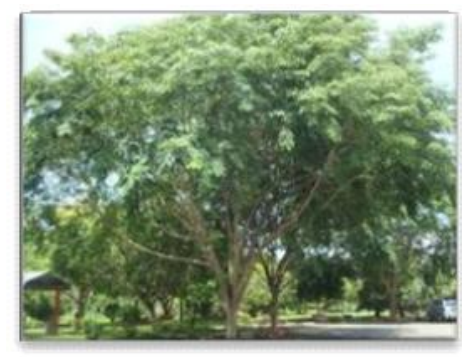

(B)

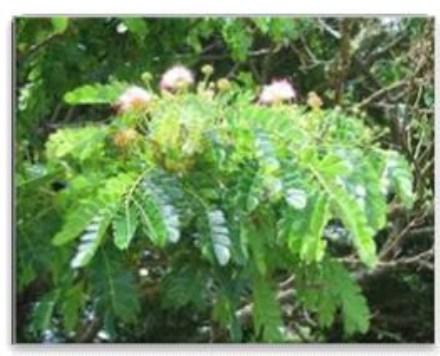

(C)

Gambar 2. (A) Akasia (Acacia mangium), (B) Angsana (Pterocarpus indicus), dan (C) Kihujan (Samanea saman)

Pohon yang sangat sesuai dalam menyerap gas polutan diantaranya terdapat akasia (Acacia mangium), angsana (Pterocarpus indicus), dan kihujan (Samanea saman).

Tiga spesies pohon tersebut memenuhi semua kriteria standar penilaian. Tiga spesies pohon tersebut memiliki tingkat kepadatan tajuk yang rapat dengan skor 3 dan sangat rapat dengan skor 4 serta penanaman yang dikombinasikan dengan semak, perdu, dan tanaman penutup tanah. Selain itu, tiga spesies pohon tersebut mempunyai ciri-ciri fisik yang menunjang dalam penyerapan polutan diantaranya berupa daun yang tipis dan berjumlah banyak. Penanaman ketiga spesies pohon tersebut ditanami dengan jarak tanam yang rapat.

Sedangkan pohon yang sesuai untuk fungsi menyerap polutan gas diantaranya adalah tanjung (Mimusops elengi), kersen (Mutigia calabura), dan ketapang (Terminalia cattapa).

\subsection{Analisis Fungsi Spesies Pohon Dominan di Kawasan Industri Semen dalam Menyerap Debu}

Kawasan hijau dapat mengurangi tingkat pencemaran partikel akibat emisi yang dikeluarkan dari kegiatan industri maupun kendaraan bermotor. Kegiatan dari industri pabrik umumnya memiliki tingkat pencemaran debu yang cukup tinggi. Pencemaran debu direduksi oleh pohon-pohon yang ditanam di sepanjang jalur hijau dengan melakukan penjerapan debu tersebut pada permukaan tanaman dengan mekanisme tertentu.

Kriteria pohon yang dapat menjerap debu dengan baik diantaranya harus memiliki permukaan daun yang kasar, berlekuk, berbulu dan bertrikoma, daun yang menjarum dan juga melebar, tajuk tanaman yang padat dan rapat, tekstur kulit batang dan ranting yang kasar serta berduri, dan kepadatan ranting yang rapat. Permukaan daun yang berbulu dan bertrikoma mampu menjerap debu lebih banyak daripada permukaan daun yang tidak berbulu dan bertrikoma. Debu yang tersebar di udara dapat menempel pada bulu dan trikoma yang terletak pada permukaan daun. Daun yang menjarum dan melebar lebih efektif dalam menyerap polutan karena memiliki luas permukaan daun yang lebih besar.

Pohon yang memiliki masa tajuk yang massif serta rapat dapat menjerap partikel yang lebih besar dan efektif daripada masa tajuk yang terbuka. Selain itu permukaan yang kasar pada struktur batang dan pada ranting juga berpengaruh terhadap kemampuan pohon dalam 
menjerap partikel. Ranting dan batang pada pohon yang memiliki struktur permukaan yang kasar dapat menjerap partikel lebih baik daripada pohon yang memiliki struktur permukaan. Kepadatan ranting yang rapat pada suatu pohon juga lebih efektif dalam menjerap partikel (Septiawan, et al. 2017).

Variabel yang digunakan untuk mengamati kesesuaian pohon dalam menjerap debu diantaranya adalah struktur permukaan daun, tepi daun yang kasar dan berlekuk, permukaan daun berbulu dan memiliki trikoma, bentuk daun yang menjarum dan melebar, kepadatan tajuk, tekstur kulit ranting dan batang kasar dan berduri serta tingkat kepadatan ranting.

Tabel 3. Skoring Kesesuaian Pohon dalam Menjerap Debu

\begin{tabular}{|c|c|c|c|c|c|c|c|c|}
\hline \multirow{3}{*}{ Nama Ilmiah } & \multicolumn{8}{|c|}{ Skoring Kemampuan } \\
\hline & \multirow[t]{2}{*}{ Nama Tanaman } & \multicolumn{5}{|c|}{ Menjerap Partikel } & \multirow[t]{2}{*}{ Nilai } & \multirow[t]{2}{*}{ Keterangan } \\
\hline & & B1 & B2 & B3 & B4 & B5 & & \\
\hline Mutingia calabura & Kersen & 4 & 1 & 4 & 2 & 4 & 75 & Sesuai \\
\hline Acacia mangium & Akasia & 1 & 3 & 4 & 3 & 3 & 70 & Sesuai \\
\hline Terminalia cattapa & Ketapang & 2 & 3 & 3 & 2 & 4 & 70 & Sesuai \\
\hline Pterocarpus indicus & Angsana & 1 & 2 & 4 & 3 & 4 & 70 & Sesuai \\
\hline Samanea saman & Ki hujan & 1 & 1 & 4 & 3 & 4 & 65 & Sesuai \\
\hline Erythrina crista galli & Dadap merah & 2 & 2 & 2 & 3 & 4 & 65 & Sesuai \\
\hline Mimushop elengi & Tanjung & 3 & 2 & 4 & 2 & 3 & 65 & Sesuai \\
\hline
\end{tabular}

Keterangan:

B1 : Struktur permukaan, tepi daun kasar, berlekuk, berbulu/bertrikoma

B2 : Daun jarum/daun lebar

B3 : Kepadatan tajuk

B4 : Tekstur kulit ranting dan batang kasar, ranting berduri

B5 : Kepadatan ranting

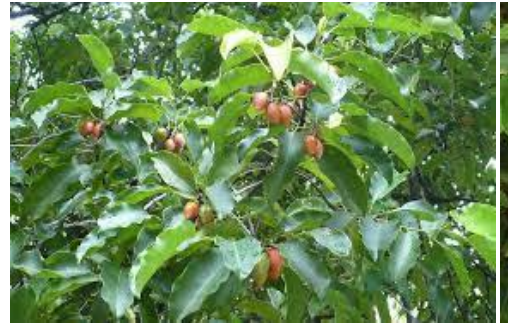

(A)

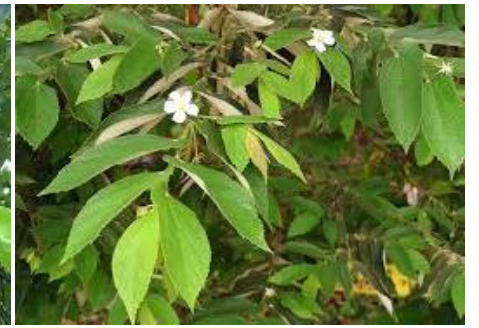

(B)

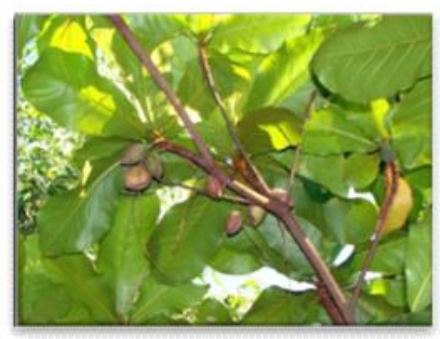

(C)

Gambar 3. (A) Tanjung (Mimusops elengi), (B) Kersen (Mutigia calabura), dan (C) Ketapang (Terminalia cattapa)

Berdasarkan hasil pengamatan seluruh spesies pohon dominan memiliki kategori sesuai dalam menjerap partikel.
Pohon-pohon yang sesuai dalam menjerap partikel diantaranya adalah kersen (Mutingia calabura), akasia (Acacia 
mangium), ketapang (Terminalia catapa), angsana (Pterocarpus indica), ki hujan (Samanea saman), dadap merah (Erythrina crista galli), dan tanjung (Mimusops elengi).

Pohon-pohon dengan kategori sesuai memiliki struktur permukaan dan tepi daun yang beragam. Pohon dengan kategori sesuai yang memiliki struktur permukaan dan tepi daun yang kasar dan agak kasar adalah kersen (Mutingia calabura). Sedangkan pohon kategori sesuai yang memiliki ciri fisik daun berlekuk diantaranya adalah tanjung (Mimusops elengi). Pohon kategori sesuai yang memiliki trikoma yang banyak adalah pohon kersen (Mutingia calabura), dan ki hujan (Samanea saman). Selain itu pohon kategori sesuai memiliki bentuk daun menjarum dan melebar seperti ketapang (Terminalia catapa). Sebagian besar pohon dengan kategori sesuai memiliki tajuk pohon yang padat dan rapat serta tekstur kulit ranting dan batang yang kasar hingga agak halus. Selain itu kepadatan ranting pohon dengan kategori sesuai juga cukup rapat. Spesies pohon ki hujan (Samanea saman) memiliki permukaan daun yang halus dan kecil sehingga kurang baik dalam menjerap partikel meskipun pohon ki hujan memiliki kepadatan tajuk yang rapat.

\section{KESIMPULAN}

Berdasarkan hasil penelitian yang telah dilakukan, maka dapat disimpulkan bahwa:

1. Spesies pohon yang sangat sesuai dapat menyerap gas polutan antara lain angsana (Pterocarpus indicus) dan ki hujan (Samanea saman) dengan nilai evaluasi $90 \%$, serta akasia (Acacia mangium) memperoleh nilai evaluasi $85 \%$.

2. Evaluasi mengenai fungsi penjerapan partikel debu menunjukkan bahwa seluruh spesies pohon dominan yang diteliti memiliki kriteria sesuai dalam menjerap debu dengan perolehan nilai evaluasi $65 \%-75 \%$.

\section{DAFTAR PUSTAKA}

Aji, Ditya Anggoro. 2018. Evaluasi Potensi Fungsi Tanaman sebagai Penyerap Polutan Gas $\mathrm{CO}_{2}$ Padaa Lanskap Jalan Regional Ring Road Kota Bogor. IPB. Bogor.

Al-Hakim, A. H. 2014. Evaluasi Efektivitas Tanaman dalam Mereduksi Polusi Berdasarkan Karakter Fisik Pohon pada Jalur Hijau Jalan Pajajaran Bogor. IPB. Bogor.

Fransiska, Nurse. 2016. Analisis Risiko Pajanan Kadar Total Suspended Particulated (TSP) di Udara Ambien Terhadap Kesehatan Masyarakat di Kawasan Industri PT Semen Padang Tahun 2016. Universitas Andalas. Padang.

Haerani, Nunung. 2012. Kadar Klorofil dan Pertumbuhan Helianthus annuus yang Terpapar Emisi Kendaraan Sebagai Bioindikator Kualitas Udara. Universitas Pendidikan Indonesia. Bandung. Hasibuan, Febriandi, Warsito., \& S.W. Suciyati. 2015. Simulasi Model Dispersi Polutan Gas dan Partikulat Molekul Pada Pabrik Semen Dengan Menggunakan Software Matlab 7.12. Jurnal Teori dan Aplikasi Fisika. Vol. 3(2). Hal: 142150. 
Hidayat, I. W. 2008. Evaluasi Jalur Hijau Jalan Sebagai Penyangga Lingkungan Sekitarnya dan Keselamatan Pengguna Jalan Bebas Hambatan Jagorawi. [Tesis]. Program Pascasarjana Institut Pertanian Bogor. Tidak dipublikasikan.

Septiawan, Wawan, Indriyanto, \& Duryat. 2017. Jenis Tanaman, Kerapatan, dan Stratifikasi Tajuk Pada Hutan Kemasyarakatan Kelompok Tani
Rukun Makmur 1 di Register 30 Gunung Tanggamus, Lampung. Jurnal Sylva Lestari. Vol. 5(2). Hal: 88-101).

Suhariyono, Gatot. 2002. Korelasi Karakteristik Partikel Debu $P M_{10} / P M_{2,5}$ dan Resiko Kesehatan Masyarakat di Rumah-Rumah Sekitar Industri Semen (Studi Kasus Pencemaran Udara di Pabrik Semen, Citeureup - Bogor). Tesis. Institut Pertanian Bogor. Bogor. 